УДК 351

H. E. XopomaєBa, здобувач магістратури кафедри управління охороною здоров' я та публічного адміністрування, Начіональний університет охорони здоров' я Украйни імені П. А. Шупика ORCID ID: 0000-0002-2420-7319

3. В. Гбур,

д. держ. упр., професор, професор кафедри управління охороною здоров' я та публічного адміністрування, Начіональний університет охорони здоров' я Украйни імені П. А. Шупика

ORCID ID: 0000-0003-4536-2438

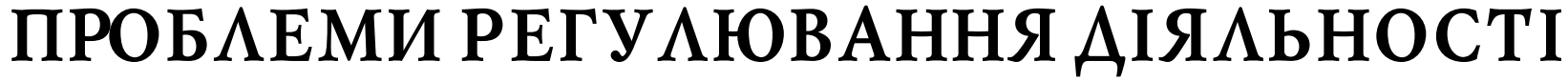 ПРАВООХОРОННИХ ОРГАНІВ
}

\author{
N. Khoroshaieva, \\ Master's student of the Department of Management health care and public administration, \\ Shupyk National Healthcare University of Ukraine, Kyiv, Ukraine \\ Z. Hbur, \\ Doctor of Sciences in Public Administration, Full Professor Professor of the Department of Healthcare \\ Management and Public Administration, Shupyk National Healthcare University of Ukraine, Kyiv, Ukraine
}

\section{PROBLEMS OF REGULATING THE ACTIVITIES OF LAW ENFORCEMENT BODIES}

У статті висвітлено рекомендації для регулювання діяльності правоохоронних органів, які повинні розглядатися відповідно до чинних стандартів прав людини, національного законодавства, передового досвіду правоохоронної діяльності та в координації з національними органами охорони здоров'я в умовах пандемії COVID-19. Продемонстровано ключову роль правоохоронних органів в умовах сучасності у підтримці впровадження заходів щодо охорони здоров'я для стримування спалаху COVID-19, так і у запобіганні конкретній злочинній діяльності, що виникає в цьому контексті. Сьогодні криза пандемії COVID-19 у галузі суспільної охорони здоров 'я стрімко перетворилась на соціально-економічну та правозахисну.

Еволюція пандемії COVID-19 сьогодні на місцевому, національному та глобальному рівнях вимагає від правоохоронних органів адаптації своєї діяльності та застосування конкретних заходів обережності. В цьому аспекті розглянемо рекомендації для регулювання діяльності правоохоронних органів, які повинні розглядатися відповідно до чинних стандартів прав людини, національного законодавства, передового досвіду правоохоронної діяльності та в координації з національними органами охорони здоров'я.

Проаналізовано жорсткі державні заходи щодо захисту населення та запобігання розповсюдженню коронавірусної інфекції. Вказано, що при прийнятті заходів реагування на кризу, спричинену пандемією COVID-19 держави обов'язково повинні дотримуватися основні принципи законності $і$ верховенства права. Розглянуто негативні непередбачувані наслідки вжитих відповідних заходів в боротьбі з COVID-19 та засоби їх нейтралізації. Відокремлено конкретні заходи регулювання діяльності правоохоронних органів щодо адаптації до умов пандемії COVID-19. Зокрема, вказані рекомендації щодо підтримки впровадження заходів з охорони здоров'я, забезпечення громадського порядку, надання підтримки у виявленні та пошуку осіб, які були в тісному контакті з підтвердженими випадками зараження коронавірусної інфекції; постачання, доставки, охорони витратних матеріалів (медичне обладнання, 3/3 тощо) до центрів охорони здоров'я, сховищ та розподільчих центрів; інформаційного повідомлення громади; профілактика специфічних незаконних дій, що виходять 3 контексту кризи COVID-19.

The article highlights recommendations for regulating the activities of lawenforcement agencies, which should be considered in accordance with current human rights standards, national legislation, best practices in law enforcement and in coordination with national health authorities in the context of the COVID-19 pandemic. The key role of law enforcement today has been demonstrated in supporting the implementation of health measures to contain the COVID-19 outbreak and in preventing specific criminal 
activity in this context. Today, the crisis of the COVID-19 pandemic in the field of public health has rapidly turned into a socio-economic and human rights one.

The evolution of the COVID-19 pandemic today at the local, national and global levels requires law enforcement to adapt its activities and take specific precautions. In this regard, we will consider recommendations for regulating the activities of law enforcement agencies, which should be considered in accordance with current human rights standards, national legislation, best practices in law enforcement and in coordination with national health authorities.

Tough government measures to protect the population and prevent the spread of coronavirus infection are analyzed. It is stated that when taking measures to respond to the crisis caused by the COVID-19 pandemic, states must adhere to the basic principles of legality and the rule of law. The negative unforeseen consequences of the appropriate measures taken in the fight against COVID-19 and the means of their neutralization are considered. Specific measures to regulate the activities of law enforcement agencies to adapt to the conditions of the COVID-19 pandemic are highlighted. In particular, recommendations are provided to support the implementation of health measures, public order, support in identifying and searching for persons who have been in close contact with confirmed cases of coronavirus infection; supply, delivery, protection of consumables (medical equipment, PPE, etc.) to health centers, warehouses and distribution centers; community information message; prevention of specific illegal actions arising from the context of the COVID-19 crisis.

Ключові слова: сВітова криза, пандемія, COVID-19, права людини, режим ізолячії, правоохоронніоргани, засоби індивідуального захисту (3/3), Вакцина, Darknet, фрішинг, кіберзлочинність, криптовалюти, грошові дропи.

Key words: global crisis, pandemic, COVID-19, human rights, isolation regime, law enforcement agencies, personal protective equipment (PPE), vaccine, Darknet, phishing, cybercrime, cryptocurrencies, money drops.

\section{ПОСТАНОВКА ПРОБАЕМИ}

Світова криза, що виникла внаслідок пандемії COVID-19 охопила різні напрями діяльності, галузі виробництва та створила загрозу встановленому в суспільстві правопорядку. Більшість країн у світі були змушені вдатись до жорстких державних заходів щодо захисту населення та запобігання розповсюдженню коронавірусної інфрекції.

Потрібно вказати, що пандемія COVID-19 призвела до прийняття виняткових заходів, що обмежують або призупиняють повноцінне та ефрективне здійснення основних прав людини, включаючи право на свободу пересування та мирні зібрання. Дійсно, такі виняткові заходи можуть бути вжиті з метою захисту здоров'я та добробуту населення або реагування на надзвичайні ситуації [10, с. 2].

Реалізація норм Конституції України вимагає підкорювати діяльність держави, органів влади й суб'єктів господарювання інтересам народу, захищати права і свободи громадян у будь-яких умовах розвитку країни. Принцип верховенства права, що проголошується в нашій країні, забезпечує виконання державою власних фрункцій у будь-який сфрері суспільства як законної діяльності, що здійснюється з метою забезпечення прав громадян, зокрема на достатній життєвий рівень, працю, відпочинок, освіту, власність тощо, а також і прав на охорону здоров'я, медичну допомогу та медичне страхування. Отже, правоохоронна функція держави реалізується як діяльність відповідних уповноважених суб'єктів у різних сфрерах суспільства з метою забезпечення їх стабільного, ефективного, закономірного й упорядкованого розвитку [2, с. 21].

Необхідно наголосити, що з моменту спалаху COVID-19 правоохоронні органи відіграли вирішальну роль у підтримці зусиль щодо боротьби з хворобою та сприянні безпеці громади, а також у боротьбі із загрозами з боку злочинців, які скористалися пандемією, щоб збільшити або диверсифрікувати свою діяльність [10, c. 3].

Таким чином, в умовах сучасності правоохоронні органи мають ключову роль як у підтримці впровадження заходів щодо охорони здоров'я для стримування спалаху COVID-19, так і у запобіганні конкретній злочинній діяльності, що виникає в цьому контексті. Еволюція пандемії COVID-19 на місцевому, національному та глобальному рівнях вимагає від правоохоронних органів адаптації своїх місій та застосування спеціальних заходів обережності. Цим, на нашу думку, обумовлена актуальність наукової розробки обраної теми щодо проблеми регулювання діяльності правоохоронних органів в умовах сучасності.

\section{AHA $\Lambda$ I АОС $\Lambda$ IАЖЕНЬ}

У сучасній науковій літературі проблематика регулювання діяльності правоохоронних органів займає важливе місце. Зокрема, питання забезпечення законності, правопорядку та правоохоронної діяльності розробляли такі науковці: А. Алексеєв, Е. Аннерс, Ю. Арзамасов, П. Бакстер, Е. Бланкенбург, В. Гиленсен, Е. Грехем, О. Жалінський, В. Карташов, В. Кудрявцев, В. Томін, І. Ростовщиков, В. Черданцев, В. Федоров та ін. Проблемам забезпечення прав людини у діяльності правоохоронних органів присвячені праці О.Ф. Андрійко, Т.Г. Андрусяка, С.С. Алексєєва, М.В. Вітрука, І.Я. Дюрягіна, А.В. Губанова, С.Д. Гусарєва, В.О. Заросила, Р.А. Калюжного, Н.В. Камінської, М.С. Кельмана, А.М. Колодія, В.В. Копєйчикова, В.В. Лазарєва, О.С. Мордовця, О.А. Лукашевої, Н.П. Матюхіної, О.В. Негодченка, М.Ф. Орзіха, В.Л. Ортинського, Т.О. Пікулі, О.В. Петришина, П.М. Рабіновича, А.В. Савченка, 
С.П. Сегеди, О.В. Тюріної, В.М. Чхіквадзе, Р.Я. Шай, Ю.С. Шемшученка, О.В. Шмоткіна, О.Н. Ярмиша та ін. В умовах сучасності питання правоохоронної діяльності висвітлені у працях А.І. Біласа, В.М. Білика, Ю.А. Ведєрнікова, А.П. Геля, Й.І. Горінецького, Є.О. Гіди, І.А. Григоренка, В.М. Дубінчака, І.В. Зозулі, А.М. Куліша, А.М. Кучука, М.І. Мельника, В.І. Осадчого, О.С. Проневича, І.В. Солов'євича, В.Г. Фатхутдінова, М.І. Хавронюка, О.В. Шмоткіна та ін.

Отже, необхідно узагальнити, що аналіз наукових досліджень продемонстрував достатнє висвітлення питань правоохоронної діяльності, але проблематика регулювання діяльності правоохоронних органів саме в умовах пандемії COVID-19 має фррагментарне висвітлення.

\section{META CTATTI}

Мета статті - висвітлити проблеми регулювання діяльності правоохоронних органів в умовах сучасності (пандемії COVID-19).

\section{ВИК ААА ОСНОВНОГО МАТЕРІААУ}

Світова спільнота зіткнулась з безпрецедентною кризою, в основі якої знаходиться глобальна надзвичайна ситуація в галузі суспільної охорони здоров'я. Вона за своїми масштабами не може зрівнятися з будьякою іншою надзвичайною ситуацією, що виникла протягом останнього століття, тому вимагає прийняття глобальних заходів реагування з далекосяжними наслідками для економічного, соціального і політичного життя суспільства. Зважаючи на виняткову ситуацію з метою збереження життя людей у країнах світу було прийнято надзвичайні заходи. А саме: загальний режим ізоляції, що вводився для уповільнення поширення вірусу; обмеження свободи пересування та ін. Ці заходи мають не тільки позитивний вплив, а й негативні наслідки, зокрема вони можуть впливати на погіршення:

- економічного та фрінансового стану людини;

- доступу до медичного обслуговування;

- забезпечення продуктами харчування;

- якості водопостачання;

- дотримання вимог санітарії;

- умов праці;

- якості освіти і дозвілля людини тощо.

Потрібно вказати, що для пом'якшення будь-яких негативних непередбачуваних наслідків необхідно вживати відповідні заходи. Зокрема, Організація Об'єднаних Націй має сьогодні потужний набір інструментів у галузі прав людини, які дозволяють державам вчасно реагувати на загрози та кризи. Спостереження за розвитком кризичерез призму прав людини змушує замислитися суспільство над тим, як вона позначається на людях, особливо на найбільш вразливих серед нас, і що з цим можливо зробити в умовах сучасності та в довгостроковій перспективі. В цьому аспекті передусім слід підкреслити, що дотримання прав людини - це обов'язок держави. Забезпечення прав людини для всіх людей в тій чи іншій мірі $є$ викликом для кожної країни в усьому світі [8, с. 2].

Сьогодні криза пандемії COVID-19 у галузі суспільної охорони здоров'я стрімко перетворилась на соціально-економічну та правозахисну. Правоохоронні органи зобов'язані сприяти боротьбі з цією хворобою і захищати людей від її наслідків. Зокрема, пандемія може служити приводом для підриву демократичних інститутів, придушення законного інакомислення тощо. Хоча у певних ситуаціях примусові заходи можуть бути виправдані, але застосовані тільки для зміцнення і підтримки національних зусиль у сорері охорони здоров'я, 3 дотриманням справедливості, правосуддя і поваги принципу верховенства права. Судова система і система правосуддя продовжують функціонувати, незважаючи на запроваджувані в зв'язку з кризою обмеження. Державні правоохоронні органи продовжують забезпечувати підтримку правопорядку, зокрема захищають всіх, у тому числі жінок, літніх людей, інвалідів та дітей від насильства і жорстокого поводження та забезпечують безперервність надання підтримки жертвам гендерного насильства під час кризи.

Велику допомогу в боротьбі з COVID-19 надають новітні технології, однак їх використання, включаючи штучний інтелект і значні дані для забезпечення дотримання обмежень, що вводяться в зв'язку з надзвичайними ситуаціями та з міркувань безпеки щодо спостереження за постраждалими або відстеження їх розташування викликає турботу та заклопотаність правоохоронних органів. Існує висока ймовірність зловживань, оскільки заходи, які виправдані під час надзвичайної ситуації, можуть залишитися в силі і після закінчення кризи. Без належних гарантій ці високоефективні технології можуть використовуватися в цілях дискримінації, вторгнення в життя людей та посягання на недоторканність приватного життя тощо. В цьому аспекті після прийняття будь-яких заходів необхідно забезпечувати значущі гарантії захисту даних, а також їх законність, доцільність і відповідність конкретним термінам, що виправдані з точки зору досягнення законних цілей в області суспільної охорони здоров'я.

Необхідно зазначити, що у деяких країнах криза підриває мирні процеси. Деякі суб'єкти користуються нею в політичних цілях. Зокрема, у ході реалізації заходів реагування на COVID-19 деякі держави прагнуть використовувати антитерористичне законодавство та заходи безпеки для обмеження прав людини. Такого роду зловживання призводить до створення умов, що сприяють поширенню тероризму [8, с. 18].

Отже, враховуючи вищевказане, можемо узагальнити, що при прийнятті заходів реагування на кризу, спричинену пандемією COVID-19 держави повинні гарантувати, зокрема, права, пов'язані з застосуванням сили, арештом іутриманням під вартою, справедливим судовим розглядом, доступом до правосуддя, забезпечення умов приватного життя. Обов'язково повинні дотримуватися основні принципи законності і верховенства права.

Еволюція пандемії COVID-19 сьогодні на місцевому, національному та глобальному рівнях вимагає від правоохоронних органів адаптації своєї діяльності та застосування конкретних заходів обережності. В цьому аспекті розглянемо рекомендації для регулювання діяльності правоохоронних органів, які повинні розглядатися відповідно до чинних стандартів прав людини, національного законодавства, передового досвіду правоохоронної діяльності та в координації з національними органами охорони здоров'я. 
Підтримка впровадження заходів з охорони здоров'я. Виходячи з ситуації на національному та місцевому рівнях, а також відповідно до міжвідомчих стратегій реагування на COVID-19, правоохоронні органи можуть брати участь у підтримці заходів контролю за впровадженням заходів з охорони здоров'я. Зокрема, у пунктах пропуску через кордон та у обмеженні руху у блокованих районах.

Рекомендації. Застосовуються заходи фрізичного дистанціювання:

- уникнення або обмеження прямого контакту з документами;

- носіння 313 (коли вони доступні та рекомендовані органами охорони здоров 'я);

- обмеження контакту та підтримання гігієни рук, під час спілкування з представниками громадськості;

- забезпечення частого прибирання та дезінфекції навколишнього середовища (провітрювання приміщень тощо) $[10$, с. 9].

Громадський порядок. Забезпечення громадського порядку є критичним у будівлях інфрраструктури та місцях, де збирається багато людей, наприклад, в аптеках та магазинах. Зокрема, будівлі критичної інфраструктури, як-от: лікарні, лабораторії, відділення міліції, центри утримання та основні підприємства повинні бути огороджені, де це необхідно. Рекомендації:

1. Застосовувати заходи фрізичного дистанціювання.

2. Мити руки та обличчя якомога частіше.

3. Очистити обладнання та робоче середовище після використання.

4. Під час проведення операцій з охорони громадського порядку покладатися на фрізичне дистанціювання не рекомендується, необхідно забезпечити працівників правоохоронних органів відповідними 3І3. Операції з охорони громадського порядку повинні проводитися відповідно до національного законодавства та з належним дотриманням міжнародних стандартів прав людини.

5. Звертати особливу увагу на підтримку громадського порядку у в'язницях та ззовні.

6. Розробити конкретні комунікаційні матеріали, пов'язані з запобіжними заходами, що стосуються центрів ізоляції, які могли б зіграти певну роль у підтримці порядку.

Контактні пацієнти. До правоохоронних органів можна звернутися за підтримкою у виявленні та пошуку осіб, які були в тісному контакті з підтвердженими випадками зараження коронавірусної інфекції. Рекомендація. Надзвичайно важливо забезпечити, щоб діяльність правоохоронних органів проводитись із суворою відповідністю національному законодавству та з належним дотриманням прав людей [10, с. 11].

Постачання, доставка, охорона витратних матеріалів (медичне обладнання, ЗІЗ тощо) до центрів охорони здоров'я, сховищ та розподільчих центрів. Рекомендація: Продумати використання приватної охорони, військового супроводу або правоохоронних органів, щоб забезпечити ці поставки та запобігти крадіжкам.

Інформаційне повідомлення громади. Правоохоронні органи можуть відігравати активну роль у передачі інформації населенню щодо національних заходів охорони здоров'я. Рекомендації:
1. Необхідно володіти еволюцією національних заходів контролю за охороною здоров'я.

2. Передавати актуальні поради та інформацію для громадськості;

3. Заохочувати міжвідомчу координацію для забезпечення послідовних повідомлень для населення.

4. Проводити відповідну роботу з фальшивими повідомленнями.

5. Інформувати громадськість про злочинні дії, пов'язані з поточним спалахом інфекції.

Профрілактика специфічних незаконних дій, що виходять з контексту кризи COVID-19. Посилення незаконної діяльності та/або намірів до її спричинення спостерігається у відповідних проявах злочинності. Це вимагає посиленої уваги з боку правоохоронних органів. Зокрема, як-от: стрес, фрінансова незахищеність, важкі умови життя або погане самопочуття. Вони можуть сприяти виникненню насилля ) [10, с. 13].

Домашнє насилля. Після впровадження заходів ізоляції правоохоронні органи повідомляють про різке збільшення випадків домашнього насилля. Багато людей знаходяться у своїх будинках, обмежуючи спілкування із зовнішнім світом. Правоохоронні органи повинні бути готові реагувати на цю світову тенденцію та виділяти відповідні ресурси для подолання кризи.

Сексуальна експлуатація дітей. Діти як жертви домашньої сексуальної експлуатації тажорстокого поводження знаходяться в ізоляції разом із злочинцем. Вони мають обмежений доступ до опікунів, таких як вчителі, лікарі та соціальні служби, які часто $є$ ключовими у виявленні та повідомленні випадків сексуальної експлуатації дітей. Ізоляція під час пандемії COVID-19 призвела до збільшення перешкод для таких дітей повідомляти про правопорушення, звертатись за медичною допомогою та іншими фрормами підтримки.

Сексуальне насильство над дітьми онлайн. Діти ризикують потрапити до сексуальної експлуатації з боку злочинців, що працюють в Інтернеті. В умовах сучасності спостерігається збільшення інформації у світовій мережі для громадськості стосовно злочинів щодо сексуального насильства над дітьми, а також активне розповсюдження матеріалів про сексуальне насильство над ними. Через умови роботи вдома під час пандемії COVID-19 зменшилась кількість модераторів, які аналізують таку інформацію, тому надходження звітів та видалення іiї може бути повільнішим та менш ефективним, ніж зазвичай.

Darknet. Правопорушники, активні в Darknet, відверто обговорюють, як пандемія COVID-19 вплинула на їх незаконну діяльність.

Рекомендації:

1. Розробити відповідну стратегію для забезпечення достатнього представництва жінок-офіцерів, які можуть виконувати обов'язки на першій лінії доступу.

2. Провести роботу з окремими групами громадянського суспільства та постачальниками соціальних послуг (наприклад, вчителями, соціальними працівниками, молодіжними групами) з метою створення комфрортних умов для звернення до них жертв домашнього насильства та людей, що перебувають у вразливих ситуаціях. 
3. Забезпечити увагою дітей та молодь, які можуть бути вразливі до зловживань або до вчинення злочинної поведінки.

4. Брати участь у інформаційних кампаніях для навчання дітей та батьків щодо безпеки в Інтернеті і стримання правопорушників.

5. Розглянути можливість включення нових каналів для звіту про випадки сексуального насильства над дітьми, як-от: обмін текстовими повідомленнями в Інтернеті, або співпраця з існуючими гарячими лініями.

6. Провести моніторинг сайтів Clearnet i Darknet для виявлення та розслідування злочинної діяльності.

7. Завантажувати матеріали про сексуальне насильство над дітьми з Міжнародної бази даних INTERPOL для аналізу і забезпечення міжнародної співпраці з питань ідентифрікації жертв та правопорушників.

Зловмисне поширення вірусної інфрекції. Правоохоронні органи повинні розглядати можливість моніторингу навмисних дій з реальним ризиком поширення інфекції (такі дії повинні додатково оцінюватися в кожному конкретному випадку). Зокрема:

- Випадки плювання на людей, кашель в обличчя правоохоронців, медичних та інших працівників, щоб залякати їх.

- Спроби навмисного інфікування.

- Повідомлення, що люди плюють і кашляють на поверхні та предмети.

- Випадки листів із погрозами, які нібито забруднені політичними діячами, що інфіковані COVID-19.

- Деякі заражені особи можуть навмисно переїжджати з постраждалих районів у інші не забруднені райони.

- Повідомлення про продаж забруднених зразків рідин в організмі через Інтернет.

Рекомендації:

1. Правоохоронці повинні бути особливо обережні у разі звернення до них осіб, які проти носіння 313.

2. У відділеннях поліції - поверхні, до яких має доступ населення, слід часто дезінфрікувати.

3. Співробітники прикордонної поліції повинні повідомляти про будь-яку особу, що має симптоми інфрікування на пунктах перетину кордону.

4. Спеціалізовані слідчі з питань кіберзлочинності або боротьби з тероризмом повинні приділяти особливу увагу інтернет-базарам.

5. Спеціалісти поштових послуг та послуг реєстрації повинні бути інфрормовані про біологічну загрозу, яку уявляють собою підозрілі пакети та дотримуватись рекомендованих заходів захисту.

6. Правоохоронці, що задіяні в охороні громадського порядку або відповідальні за захист відомих громадських діячів повинні бути проінформовані про ризики зловмисного інфрікування.

Збільшення кількості підроблених медичних виробів, доступних на ринку, зокрема:

- одноразові хірургічні маски;

- дезінфікуючі засоби для рук;

- противірусні засоби та ліки;

- вакцини;

- тестові набори COVID-19.

Рекомендації: Правоохоронні органи повинні звертати особливу увагу до наведеного вище списку підроб- лених медичних виробів. Про це має бути проінформована широка громадськість та знешкоджена неправдива або оманлива інтернет-реклама, яка пов'язана з цими продуктами. Слід використовувати національні "гарячі лінії" щодо виявлення такого шахрайства на ранній стадії.

Шахрайство та шахрайські грошові схеми. Ці схеми можна класифікувати так:

Інтернет-шахрайство: шахраї створюють шахрайські вебсайти, платформи електронної комерції, аккаунти у соціальних мережах та електронні листи, які стверджують, що шахраї продають і доставляють медичні вироби. У деяких випадках вони використовують назви відомих компаній, які беруть участь у виробництві та розподілі цих предметів. Потім проводять платежі за допомогою банківського переказу.

Телефонне шахрайство: Злочинець телефонує до людей похилого віку і прикидається родичем, який знаходиться в лікарні. Потерпілих просять оплатити вартість медичного лікування, перерахувавши гроші або заплативши готівкою підробленим представникам охорони здоров'я.

Фішинг: листи або електронні листи пов'язані з пандемією, надсилаються злочинцями з метою обману підключення до певної вебсторінки та входу за допомогою справжньої адреси електронної пошти та пароля. Потім шахраї використовують свої облікові дані для доступу до конфріденційної інфрормації та потенційного викрадення коштів.

Зловживання державними коштами: Злочинці клонують урядові вебсайти та підробляють документи для подання заявок іїх розповсюдження.

Накопичення готівки: злочинні угруповання стикаючись із труднощами при переміщенні фрізичної готівки чекають скасування обмежень на подорожі, щоб відновити масові перевезення готівки.

Прикриття бізнесу COVID-19: злочинці, які використовують обладнання або послуги, пов'язані зі здоров'ям, приховують підозрілі операції з метою інтеграції грошей у легальну економіку.

Нерегульовані фрінансові послуги: незаконні гроші можуть бути використані для фрінансування підприємств та осіб, які мають фінансові труднощі, що спонукає їх відійти від офріційної банківської кредитної системи. Кошти продовжують переміщуватися через нерегульовані послуги, як-от: Hawala або криптовалюти.

Грошові мули / дропи: злочинці можуть набирати грошових мулів (банківські рахунки або осіб) протягом періоду відновлення, орієнтуючись на безробітних або осіб, які борються з фінансовими проблемами. Мережі облікових записів мулів можуть бути використані для здійснення міжнародних операцій з грошима, отриманими від шахрайства під час пандемії COVID-19.

Інші шахрайства: злочинці вдають, що представляють інвестиційні компанії, благодійні організації COVID19 , або можуть виступати в ролі урядовців.

Рекомендації: Правоохоронні органи повинні попередити населення про ці злочини за допомогою публічних повідомлень.

Кіберзлочинність. Кількість шкідливих програм з використанням COVID-19 та зараженням комп'ютерних систем приватних осіб і організацій продовжують зрос- 
тати. Кіберзлочинці націлені на сайти, де доступ до системи або дані $є$ критично важливими для розгортання програмних вимог. Це дозволяє їм вимагати вищого викупу. Такі організації, як уряди, важлива інфраструктура та сектор охорони здоров'я, зазнають особливого ризику. Загрози безпеці також пов'язані з використанням віддаленої робочої сили.

Рекомендації:

Для фрізичних осіб:

- уникайте відкривання підозрілих електронних листів і натискання на посилання на нерозпізнані електронні листи та вкладення;

- регулярно створюйте резервні копії фрайлів у мережі та в режимі офрлайн;

- використовувати надійні паролі;

- зберігати сучасне програмне забезпечення, включаючи антивірусне програмне забезпечення.

Для компаній:

- Посилити найкращі практики та набори з кібербезпеки, мати чіткі рекомендації щодо віддаленої роботи.

- Встановити антивірусні сканери та антивірусне програмне забезпечення на всіх комп'ютерах компанії та інших пристроях.

- Забезпечити достатню цифрову ємність і повний диск шифррування на корпоративних пристроях; підтримувати видимість на цих пристроях.

- Впровадити сегментацію мережі та зберегти пристрої, що відокремлюються від інших критично важливих систем та мереж.

- Інвестувати в багатофакторну автентифікацію незалежно від розміру бізнесу ) [10, с. 19].

Потрібно наголосити, що еволюція епідеміологічної ситуації впливає на впровадження нових обмежувальних заходів. Спираючись на рекомендації щодо впровадження заходів з охорони здоров'я, правоохоронна діяльність відновлюється безпечним чином, тому правоохоронним органам рекомендується підготувати план відновлення бізнесу. В цьому аспекті план відновлення повинен враховувати нову ситуацію злочинів, а також збільшення службових обов'язків, пов'язаних із "поверненням до нормального стану" діяльності. Правоохоронні органи повинні продовжувати забезпечувати здоров'я та безпеку своїх службовців, також заохочуються кампанії з обміну повідомленнями для кращого інорормування населення про нові правила взаємодії з правоохоронними органами (зокрема при повідомлення про злочин у поліцейському відділенні).

Отже, необхідно узагальнити, що співпраця правоохоронних органів та охорони здоров'я на національному рівні $€$ надзвичайно важливою і повинна керуватися будь-яким рішенням, пов'язаним із виконанням плану відновлення.

\section{ВИСНОВКИ}

Таким чином, можемо узагальнити, що з урахуванням обставин, які створює у світі пандемія, спричинена вірусом COVID-19, забезпечення реалізації правоохоронної функції держави як на національному, так і на міжнародному рівні потребує пошуку з боку уповноважених органів сучасних заходів захисту демократичних прав і свобод громадян. При прийнятті заходів реагу- вання на кризу, спричинену пандемією COVID-19 держави повинні гарантувати, зокрема, права, пов'язані з застосуванням сили, арештом і утриманням під вартою, справедливим судовим розглядом, доступом до правосуддя, забезпечення умов приватного життя. Обов'язково повинні дотримуватися основні принципи законності і верховенства права.

В умовах сучасності еволюція пандемії COVID-19 на місцевому, національному та глобальному рівнях вимагає від правоохоронних органів адаптації своєї діяльності та застосування конкретних заходів обережності. У цьому аспекті, на нашу думку, необхідно дотримуватись відповідних рекомендації для регулювання діяльності правоохоронних органів, які повинні розглядатися відповідно до чинних стандартів прав людини, національного законодавства, передового досвіду правоохоронної діяльності та в координації з національними органами охорони здоров'я.

COVID-19 - це глобальний виклик не лише для правоохоронних органів, а й для суспільства в цілому. Пандемія не має кордонів, тому індивідуальні та колективні реакції громадськості мають важливе значення для зменшення її поточного та майбутнього впливу. Правоохоронним органам та суспільній громаді важливо співпрацювати для ефективного вирішення загрози COVID-19. Повага, захист прав людей та співпраця із суспільною громадою не тільки сприяє виконанню запитів правоохоронців, але й забезпечує основне значення прав людини у формуванні реакції на пандемію в умовах сучасності.

Література:

1. Актуальні проблеми правоохоронної діяльності та національної безпеки держави: збірник тез доповідей Міжнародної наукової Інтернет конференції молодих вчених. Тернопіль, 2020. 300 с.

2. Бандурка О.М. Правоохоронна функція держави в умовах пандемії. Актуальні питання діяльності суб'єктів господарювання в умовах пандемії COVID-19: матеріали Міжнар. наук.-практ. конф. МВС України, Харків. нац. ун-т внутр. справ. Харків: ХНУВС, 2021. $348 \mathrm{c}$.

3. Вплив пандемії коронавірусу COVID-19 на права, свободи і безпеку людини в інформаційній сорері: Матеріали науково-практичної студентської конференції. / Упоряд.: Фурашев В.М., Петряєв С.Ю. Київ: Вид-во "Політехніка". 2020.196 с.

4. Денисов С. Ф. Сучасні детермінанти злочинності в Україні. Вісник Національної академії прокуратури України. 2019. № 4. С. 21-33.

5. Забезпечення правопорядку в умовах коронакризи: матеріали панельної дискусії IV Харків. міжнар. юрид. фроруму / Редкол.: В.Я. Тацій, А.П. Гетьман, Ю.Г. Барабаш, Б.М. Головкін. Харків: Право. 2020. $250 \mathrm{c}$.

6. Про запобігання поширенню на території України гострої респіраторної хвороби COVID-19, спричиненої коронавірусом SARS-CoV-2: Постанова Кабінету Міністрів України від 11 березня 2020 р. № 211. Офріційний вісник України. 2020. № 23. Ст. 896.

7. Сучасна наука і правоохоронна діяльність: тези доп. учасників XXVIII наук.-практ. конфр. курсантів та 
студентів / МВС України, Харків. нац. ун-т внутр. справ, Наук. т-во студентів, курсантів, слухачів, аспірантів, ад'юнктів, докторантів і молодих учених. Харків: ХНУВС. 2021.312 c.

8. COVID-19 и права человека: это наше общее дело. Апрель 2020 года. 24 с. URL: https://www.un.org/ sites/un2.un.org/files/human_rights_and_covid19_russian.pdf

9. CO-VID-19: Європа застерігає від аферистів на тлі пандемії коронавірусу. URL: https://www.dw.com/uk/ covid-19-yevropol-zasterihaie-vidaferystiv-na-tlipandemii-koronavirusu /a-52956242

10. The COVID-19 pandemic: Interpol's legislative recommendations. 2020. 28 p. URL: https://www.interpol.int / content / download/15793/file /COVID$19 \% 20$ Guidelines $\% 20$ for $\% 20$ Law $\% 20$... November\%202020.pdf

11. Edith Lederer, "Crime Rates Plummet Around the World as the Coronavirus Keeps People Inside," Time. April. 11. 2020. URL: https://time.com/5819507/ crimedrop-coronavirus /

12. Pandemic profiteering: how criminals exploit the COVID-19 crisis. March. 2020. URL: file:///C:/Users / iMac/Downloads/pandemic_profiteeringhow_criminals_exploit_the_covid-19_crisis.pdf

13. Phillips, Kenny Jacoby, $\bar{M}$ ike Stucka and Kristine Crime rates plummet amid the coronavirus pandemic, but not everyone is safer in their home. USA. TODAY. URL: https://www.usatoday.com/story/news/investigations /2020/04/04/coronavirus-crime-rates-dropand-domestic-violence-spikes /2939120001/

14. Viral marketing Counterfeits, substandard goods and intellectual property crime in the COVID-19 pandemic. URL: file:///C:/Users/iMac/Downloads/report_covid_19_-viral_marketing_counterfeits \%20(1).pdf

15. Usher K., Durkin J., Bhullar N. The COVID-19 Pandemic and Mental Health Impacts. International Journal of Mental Health Nursing. 2020. № 29. P. 315-318.

References:

1. West Ukrainian National University (2020), Aktualjni problemy pravookhoronnoji dijaljnosti ta nacionaljnoji bezpeky derzhavy: zbirnyk tez dopovidej Mizhnarodnoji naukovoji Internet konferenciji molodykh vchenykh. [Current issues of law enforcement and national security: a collection of abstracts of the International Scientific Internet Conference of Young Scientists], West Ukrainian National University, Ternopil, Ukraine.

2. Bandurka, O. M. (2021), "Law enforcement function of the state in a pandemic", Aktual'ni pytannia diial'nosti sub'iektiv hospodariuvannia $v$ umovakh pandemii COVID19 : materialy mizhnar. nauk.-prakt. konf. [Current issues of business entities in the COVID-19 pandemic: materials of the international scientific-practical conf.], KhNUVS, Kharkiv, Ukraine.

3. Furashev, V. M. and Petriaiev, S. Yu. (2020), Vplyv pandemiji koronavirusu COVID-19 na prava, svobody $\mathrm{i}$ bezpeku ljudyny $v$ informacijnij sferi [The impact of the COVID-19 coronavirus pandemic on human rights, freedoms and security in the information sphere: Proceedings of the scientific-practical student conference.], Polytechnic Publishing House, Kyiv, Ukraine.
4. Denysov S. F. (2019), "", Modern determinants of crime in Ukraine, Visnyk Natsional'noi akademii prokuratury Ukrainy, vol. 4, pp. 21-33.

5. Tatsij, V. Ya. Het'man, A. P. Barabash, Yu. H. and Holovkin, B. M. (2020), Zabezpechennja pravoporjadku v umovakh koronakryzy: materialy paneljnoji dyskusiji IV Kharkiv. mizhnar. juryd. Forumu [Ensuring law and order in the context of the corona crisis: materials of the panel discussion IV Kharkiv. international jurid. Forum], Law, Kharkiv, Ukraine.

6. Cabinet of Ministers of Ukraine (2020), Resolution "On prevention of the spread on the territory of Ukraine of acute respiratory disease COVID-19 caused by coronavirus SARS-CoV-2", Ofitsijnyj visnyk Ukrainy, vol. 23.

7. KhNUVS (2021), Suchasna nauka i pravookhoronna dijaljnistj: tezy dop. uchasnykiv XXVIII nauk.-prakt. konf. kursantiv ta studentiv [Modern science and law enforcement: theses add. participants of the XXVIII scientific-practical. conf. cadets and students], KhNUVS, Kharkiv, Ukraine.

8. UN (2020), "COVID-19 and human rights: this is our common cause", available at: https://www.un.org/ sites/un2.un.org/files/human_rights_and_covid19_russian.pdf (Accessed 20 July 2021).

9. Rigert, B. (2020), "COVID-19: Europe warns against scammers against the background of the coronavirus pandemic", available at: https://www.dw.com/uk/covid19-yevropol-zasterihaie-vidaferystiv-na-tli-pandemiikoronavirusu /a-52956242 (Accessed 20 July 2021).

10. Interpol (2020), "The COVID-19 pandemic: Interpol's legislative recommendations", available at: https://www.interpol.int/content/download/15793/ file / COVID- $19 \% 20$ Guidelines $\% 20$ for $\% 20$ Law $\%$ 20...November \% 202020.pdf (Accessed 20 July 2021).

11. Lederer, E. (2020), "Crime Rates Plummet Around the World as the Coronavirus Keeps People Inside", available at: https://time.com /5819507/crimedropcoronavirus / (Accessed 20 July 2021).

12. Europol (2020), "Pandemic profiteering: how criminals exploit the COVID-19 crisis March 2020", available at: https://www.europol.europa.eu/publications-documents / pandemic-profiteering-how-criminals-exploit-covid-19-crisis (Accessed 20 July 2021).

13. Jacoby, K. Stucka, M. and Phillips, K. (2020), "Crime rates plummet amid the coronavirus pandemic, but not everyone is safer in their home", available at: https:/ /www.usatoday.com/story/news/investigations / 2020/04/04/coronavirus-crime-rates-drop-and-domestic-violence-spikes/2939120001/ (Accessed 20 July 2021).

14. Europol (2020), "Viral marketing Counterfeits, substandard goods and intellectual property crime in the COVID-19 pandemic", available at: https://www.europol.europa.eu/publications-documents/viral-marketingcounterfeits-substandard-goods-and-intellectualproperty-crime-in-covid-19-pandemic (Accessed 20 July 2021).

15. Usher, K., Durkin, J. and Bhullar, N. (2020), "The COVID-19 Pandemic and Mental Health Impacts ", International Journal of Mental Health Nursing, vol. 29, pp. $315-318$.

Стаття надійшла до редакиї 29.07.2021 p. 